\title{
How do Disturbance-Generated Patterns INFLUENCE THE SPATIAL DYNAMICS OF ECOYSTEM PROCESSES?
}

\author{
MONICA G. TURNER $\uparrow$ DEPARTMENT OF ZOOLOGY \\ UNIVERSITY OF WISCONSIN $\uparrow$ MADISON \\ WILLIAM H. ROMME $\uparrow$ DEPARTMENT OF FOREST SCIENCES \\ COLORADO STATE UNIVERSITY $\downarrow$ FORT COLLINS \\ DANIEL B. TINKER $\uparrow$ DEPARTMENT OF BOTANY \\ UNIVERSITY OF WYOMING $\uparrow$ LARAMIE
}

\begin{abstract}
$\uparrow$ BACKGROUND
Our studies following the 1988 Yellowstone fires demonstrated that succession was surprisingly more variable in space and time than even current theory would have suggested, and that initial spatial patterns of disturbance may persist to produce longlasting changes in vegetation. Our focus now is on explaining the spatial and temporal patterns of succession and understanding how these patterns influence ecosystem function. The most interesting new questions revolve around the degree to which the spatial variation in postfire vegetation in particular, the six orders of magnitude variation in pine sapling density, ranging from 0 to greater than 500,000 saplings/ha controls the spatial variability in ecosystem processes across the landscape. In our current research, we are conducting studies in both Grand Teton and Yellowstone National Parks to answer four major questions:
\end{abstract}

1. Does the spatial heterogeneity of processes such as ANPP, nitrogen mineralization, and decomposition change with time since fire? How quickly do spatial patterns in processes develop following a large fire?
2. How does the spatial pattern of coarse woody debris vary across the post-1988 landscape, and what is the importance of this variation for ecosystem function? Are patterns of coarse woody debris abundance related to both prefire stand structure and postfire sapling density?

3. Do the enormous differences in postfire tree density produce differences in carbon and nitrogen availability across the landscape? Or, is nutrient availability governed largely by broad-scale (i.e., $10 \mathrm{~s}$ of $\mathrm{km}$ ) abiotic gradients (e.g., climate, substrate) and/or fine-scale (i.e., less than $10 \mathrm{~cm}$ ) heterogeneity in resources or the microbial community, such that nutrient variability is not sensitive to the spatial variation in plant community structure?

4. Does the disturbance-created mosaic leave a persistent functional legacy? What mechanisms in vegetation development may contribute to convergence (or divergence) in ecosystem structure and function across the landscape as succession proceeds? 


\section{FINDINGS AND STATUS}

\section{Studies in Grand Teton National Park}

Question 1: We initiated field studies during summer of 2001 in ten 0.25 -ha plots located within two fires that occurred during the summer of 2000: the Moran Fire, on the west side of Jackson Lake at the base of Mount Moran; and the Glade Fire, in the Rockefeller Parkway lands just south of the boundary of Yellowstone National Park. Within each of these fire sites, five study plots were established in areas of stand-replacing fire, three in crown fire and two in severe-surface burns. We are studying the development of postfire vegetation, sampling the number and species of tree seedlings and the percent cover (by species) of all other vegetation; the availability of inorganic nitrogen using ion-exchange resin that is incubated in the field for a year in small soil cores; the concentration of nitrogen in the vegetation of different species in the burned plots and adjacent unburned locations; and the presence and abundance of soil microbial functional groups. We are using a cyclic sampling design derived from spatial statistics and designed to detect the spatial scale of variation in nutrient availability, and we are remeasuring these sites through successional time. We will estimate herbaceous aboveground net primary production and leaf area in these recently burned stands because we expect the rate of recovery of these processes to influence nitrogen and carbon availability. Changes in spatial patterns and in mean rates of all response variables are being tracked through time by repeating the measurements through 2004.

Although not as extensive as the 1988 fires, the 2000 fires created a spatial mosaic of variable fire severity, similar to 1988 . Vegetation patterns after the 2000 fires were mostly similar to those after 1988. Pine seedlings established primarily in the first 2 years post-fire; densities were $>3 \mathrm{X}$ greater in stands of severe surface fire than in stands of crown fire, and up to $10 \mathrm{X}$ greater in the site with higher cone serotiny ( $30 \%$ vs $5 \%$ serotinous trees). Total biotic cover was uniformly low in year $1(<5 \%)$ but increased to $23-44 \%$ by year three, and was consistently higher (but slightly so) in stands of severe surface burn than in stands of crown fire. Species richness also was slightly greater in stands of severe surface burn, and richness increased only slightly after year 1 . The greatest difference after 2000 vs. 1988 was in absolute densities of pine seedlings, which were an order of magnitude lower after the 2000 fires than after the 1988 fires. The reason may be drier conditions after 2000. Moisture in the first winter after 2000 was only half that after 1988 , and mean winter moisture in the first three years after 2000 was only $85 \%$ of that after 1988 .

Thus far, we have observed little spatial structure in the nitrogen mineralization rates, as hypothesized. Vegetation patterns are generally similar to early succession following the 1988 fires, although the density of lodgepole pine saplings is considerably lower. During 2003, we resampled all ten plots located in the Glade and Moran fires. Initial processing of samples was completed in the field, but extensive laboratory analyses are currently in progress at the University of Wisconsin-Madison. Initial results indicate that, among stands, net nitrate availability averaged $14.9 \mathrm{mg} \mathrm{N} * \mathrm{~kg} \mathrm{soil}^{-1} * \mathrm{yr}^{-1}$ in 2002 and increased to $27.7 \mathrm{mg} \mathrm{N} * \mathrm{~kg} \mathrm{soil}^{-1} * \mathrm{yr}^{-1}$ in 2003. Variation in nitrate availability was explained by percent cover of charred litter, coarse woody debris, and graminoids $\left(\mathrm{r}^{2}=0.82\right)$. Ammonium availability ranged from -30.7 to $22.2 \mathrm{mg} \mathrm{N} * \mathrm{~kg}$ soil $^{-1} * \mathrm{yr}^{-1}$ in 2002 , did not differ between years, and its variation was not explained by measurements of aboveground cover. Fine-scale variation in net $\mathrm{N}$ mineralization following stand-replacing fire may reflect heterogeneity of substrates and microbial communities in the soil, although feedbacks between vegetation and net $\mathrm{N}$ mineralization may develop as succession proceeds.

Under direction of two postdoctoral associates (Drs. Erica Smithwick and Kristine Metzger), stable isotope uptake studies to determine whether different plant species were taking up inorganic nitrogen, organic nitrogen, or both were continued in the Huckleberry Ridge area burned in 1988 and adjacent unburned forest. These samples are also presently being analyzed. Initial results obtained from samples collected in 2002 provide evidence that young (2-yr old) post-fire lodgepole pine seedlings can take up organic nitrogen in its intact form. In 2003, nitrogen uptake was measured using stable isotope uptake in a stand burned during the 1988 fires and in unburned forest about 170 years of age near the Glade Fire.

In 2003, we also initiated a small fertilization study in the Glade Fire in which replicate plants of several target species received a modest fertilizer amendment. Plant growth will be measured during summers of 2004 and 2005 to determine whether there was a response to the treatment. Although nitrogen is considered to be limiting to vegetation growth throughout the subalpine forests of the Rocky Mountains, studies have not empirically demonstrated this limitation in early successional 
postfire forests.

\section{Studies in Yellowstone National Park}

During the summer of 2003, our field studies focused on questions associated with the ecological role of postfire coarse woody debris and with convergence or divergence in ecosystem structure and function through time.

Question 1. Fires again burned in the Yellowstone ecosystem during summer of 2003. Previously, all of our measurements of nutrient cycling were begun at least one year following fire. To estimate net nitrogen mineralization rates soon after stand replacing fire,we initiated studies of nitrogen mineralization rates and vegetation in areas that burned during the summer of 2003 in September. Three 0.25-ha plots were established in the East Fire (near the East Entrance Road in Yellowstone) and were paired with comparable unburned plots located east of West Thumb. These areas will be re-sampled during summer 2004.

Question 2. We initiated studies in 2002 of the influence of postfire coarse woody debris on soil nutrient dynamics and decomposition in three locations burned in the 1988 fires under the leadership of co-PI Dr. Daniel B. Tinker and postdoctoral associate Dr. Kristine Metzger. At each site, we collected soil samples from positions located under trees that have fallen since the 1988 fires, under wood that was down prior to the 1988 fires, under lodgepole pine saplings, and out in the open. The effect of coarse woody debris on nitrogen availability was measured using 1-yr incubations of ion exchange resin placed in soil cores at each site during summer 2002. Cores were removed during summer 2003, and integrated measure of nitrate and ammonium production will be obtained for a yearly time step. In addition, we are characterizing the microbial community composition of the soil, enzyme activity levels, and gross nitrogen mineralization in the laboratory.

Decomposition studies were also initiated in 2002 by placing litterbags containing herbaceous litter or conifer litter in each of the positions described above. These decomposition studies are continuing for two years. Half the bags were retrieved during summer 2003, and the remainder will be collected during summer 2004; this study will form the basis of a MS thesis for Alysa Remsburg, student at University of Wisconsin. In addition to obtaining mass loss estimates, the microfauna associated with decomposition are being quantified from the litterbags retrieved in 2003. Monitoring of microclimate conditions as they vary with treatment is also continuing at all sites. Litter mass loss from 2002-2003 indicated that decomposition rates were significantly lower under post-1988 suspended logs (mean mass loss $6.8 \%$ for needles; $27.1 \%$ for herbaceous litter) than at all other microsites (mean mass loss ranged from $12.7-16.1 \%$ for needles and from $33.2-40.3 \%$ for herbaceous litter). Following Tullgren funnel extractions from litterbags, microarthropod density and diversity were higher beneath recent and decayed logs contacting the ground than at other microsite conditions. Observed differences beneath CWD on the ground and CWD suspended in piles of multiple logs suggest that disturbance size and type can influence ecosystem processes by altering CWD accumulation patterns.

Initial results also suggest some within-stand variation in nitrogen cycling rates. In situ net $\mathrm{N}$ mineralization in the exposed mineral soil was almost twice as high $\left(15.7 \mathrm{mg}^{*} \mathrm{Kgsoil}^{-1} * \mathrm{yr}^{-1}, \mathrm{SE} \pm 2.4\right)$ and significantly different than all other treatments $(\mathrm{p}<$ 0.0001 ) yet the lab (gross) $\mathrm{N}$ mineralization was not different among treatments or by site. Lipid abundance (phospholipid fatty acid analysis) varied slightly by site $\left(\mathrm{R}^{2}=0.08, \mathrm{p}=0.03\right)$ but was not significantly different among treatments. Non-metric multi-dimensional scaling, a common ordination technique, showed the microbial community composition was different among treatments (2-axis cumulative $\mathrm{R}^{2}=0.65$ ) as was the enzymatic activities ( 2 -axis cumulative $\mathrm{R}^{2}=0.96$ ). Additionally, specific enzyme activities were correlated with lipids indicating a connection between the microbial composition and enzymatic activity. Fire-generated forest structure can create broad-scale heterogeneity across the landscape but also introduces fine-scale variation in ecosystem processing.

To explain and predict variation in the rates of treefall and abundance of postfire coarse woody debris, extensive sampling was begun during summer 2002 to quantify downed wood throughout the area burned by the 1988 fires. This sampling was continued during summer 2003, and the combination of the intensive process-based measurements with the broad-scale analysis of coarse woody debris will enhance understanding of these effects at landscape scales. This study is the basis of a MS thesis for Heather Lyons, student at Colorado State University, which should be completed during 2004. Alysa Remsburg also placed litterbags in 20 stands, all burned in 1988 but varying in their abundance of coarse woody debris, to determine whether there were stand-level effects of the postfire treefall on 
decomposition. These will also be retrieved in 2004.

Question 3. During summer 2003, we re-sampled 16 0.25-ha plots within the 1988 burn from a larger sample of 90 plots that were sampled during summer 1999. Our goals were to re-estimate aboveground net primary production and leaf area and to characterize gross nitrogen mineralization and microbial community composition in the soil, to determine whether there is a detectable effect of lodgepole pine density. In addition, we sampled the abundance of cones on the lodgepole pine saplings in each of the stands, and also harvested some of the 15-yr old pine saplings to test the allometric relationships used to predict ANPP and leaf area. Initial analyses indicated that the allometric relationships developed in 1999 still hold well for lodgepole pine saplings in 2003. Aboveground net primary production has continued to increase in many of the stands.

Question 4. Field sampling to address this question was conducted during summer 2002; this study was led by postdoctoral associate Dr. Erica A. H. Smithwick. Soils and vegetation were analyzed in 20 lodgepole pine (Pinus contorta) forest stands, varying in age from 50 to 350 years, that had initiated following stand-replacing fire. Our goal was to determine how nitrogen availability $\left(\mathrm{NH}_{4}{ }^{+} \mathrm{N}\right)$ and microbial community composition varied with stand age-class and to determine whether differences could be explained by canopy, soil, or understory characteristics. Gross $\mathrm{NH}_{4}^{+}$mineralization was measured using laboratory isotopic pool dilution and microbial community composition was evaluated using microbial membrane lipids. The microbial community composition of stands in the 300-350 age class was distinct from stands in younger age classes. Microbial community composition among sites varied with $\mathrm{pH}, \%$ organic matter, and phosphorus. Gross $\mathrm{NH}_{4}{ }^{+}$mineralization rates averaged $1.45 \pm 0.07$ $\mathrm{mg} \mathrm{NH}_{4}{ }^{+} \mathrm{kg} \mathrm{soil}^{-1} \mathrm{~d}^{-1}$ while consumption averaged $1.37 \pm 0.20 \mathrm{mg} \mathrm{NH}_{4}{ }^{+} \mathrm{kg} \mathrm{soil}^{-1} \mathrm{~d}^{-1}$, resulting in low net $\mathrm{NH}_{4}{ }^{+}$mineralization rates $\left(0.08 \pm 0.18 \mathrm{mg} \mathrm{NH}_{4}{ }^{+} \mathrm{kg}\right.$ soil $\left.^{-1} \mathrm{~d}^{-1}\right)$, but rates were not significantly different with stand age-class at $\mathrm{p}<0.05$. At $\mathrm{p}<0.10$, net $\mathrm{NH}_{4}{ }^{+}$ mineralization was significantly higher in the 300 350 age class compared to the 125-175 age class. None of the measured variables significantly explained $\mathrm{NH}_{4}{ }^{+}$consumption and net mineralization patterns. However, gross $\mathrm{NH}_{4}{ }^{+}$mineralization rates were best explained by information on microbial community structure (i.e., lipids). Variation among stands within a given age-classes was high, indicating that predictions of $\mathrm{N}$ cycling across landscapes must account for substantial heterogeneity among mature stands.

\section{ACKNOWLEDGEMENT}

This research is supported by a grant from the Andrew W. Mellon Foundation. 